\title{
Evidence of trans-Atlantic movement and natal homing of bluefin tuna from stable isotopes in otoliths
}

\author{
Jay R. Rooker ${ }^{1, *}$, David H. Secor ${ }^{2}$, Gregorio DeMetrio ${ }^{3}$, Alan J. Kaufman ${ }^{4}$, \\ Antonio Belmonte Ríos ${ }^{5}$, Vjekoslav Tičina ${ }^{6}$ \\ ${ }^{1}$ Department of Marine Biology, Texas A\&M University, 5007 Avenue U, Galveston, Texas 77551, USA \\ ${ }^{2}$ Chesapeake Biological Laboratory, University of Maryland Center for Environmental Science, PO Box 38, Solomons, \\ Maryland 20688, USA \\ ${ }^{3}$ Department of Animal Health and Well-Being, University of Bari, Casamassima km 3, 70010 Valenzano (Bari), Italy \\ ${ }^{4}$ Department of Geology, University of Maryland, College Park, Maryland 20742, USA \\ ${ }^{5}$ Tuna Graso, S.A., Carretera de la Palma km 7, Paraje la Estrella, 30593 Cartagena (Murcia), Spain \\ ${ }^{6}$ Institute of Oceanography and Fisheries, Set. I. Mestrovica 63, 21000 Split, Croatia
}

\begin{abstract}
Stable carbon and oxygen isotopes in the otoliths of Atlantic bluefin tuna Thunnus thynnus were used to investigate trans-Atlantic movement and natal homing behaviors. Otolith $\delta^{13} \mathrm{C}$ and $\delta^{18} \mathrm{O}$ of yearling bluefin tuna from 6 different year classes (1999 to 2004) were characterized to validate the approach and assess inter-annual variation in these markers for individuals from eastern (Mediterranean Sea/eastern Atlantic Ocean) and western (USA Atlantic Ocean) nurseries. Otolith $\delta^{18} \mathrm{O}$ of yearlings from the eastern nursery were enriched relative to their western counterparts, while otolith $\delta^{13} \mathrm{C}$ was relatively similar between nurseries. Temporal variability in otolith $\delta^{13} \mathrm{C}$ and $\delta^{18} \mathrm{O}$ of bluefin tuna was observed; nevertheless, classification success to eastern and western nurseries was relatively high $(87 \%)$ when all year classes were pooled. Otolith $\delta^{13} \mathrm{C}$ and $\delta^{18} \mathrm{O}$ of yearlings were then used as a baseline sample ('eastern' and 'western' nursery signature) to predict the origin of adolescents (20 to $70 \mathrm{~kg}$ ) from 1 foraging area (USA Atlantic Ocean) and adults (>140 kg) from 1 spawning ground (Mediterranean Sea) based on otolith core signatures (corresponding to yearling period). Mixed-stock analysis indicated that approximately $60 \%$ of the adolescent bluefin tuna collected from foraging areas in the USA Atlantic Ocean originated from the eastern nursery, suggesting that substantial trans-Atlantic movement of adolescents from east to west occurred. In addition, natal homing was well developed, with $94 \%$ of the adult bluefin tuna collected in the Mediterranean Sea derived from the eastern nursery. Findings from this study suggest that USA fisheries depend upon migrants of Mediterranean origin and that mixing across the $45^{\circ} \mathrm{W}$ management boundary is substantially higher than assumed previously.
\end{abstract}

KEY WORDS: Otolith chemistry - Mixed stock fishery - Stable isotopes - Stock identification · Population structure

\section{INTRODUCTION}

Management of Atlantic bluefin tuna Thunnus thynnus is based on the 2 stock hypothesis ('east' versus 'west'), with spawning occurring east (Mediterranean Sea) and west (Gulf of Mexico) of the $45^{\circ} \mathrm{W}$ management boundary. Although trans-Atlantic migration of members from both populations has been documented (Lutcavage et al. 1999, Block et al. 2001, 2005), fidelity to natal areas is assumed, justifying the 2 stock hypothesis used by the International Commission for the Conservation of Atlantic Tunas (ICCAT). Still, the relative magnitude of trans-Atlantic movement and mixing, and the timing and extent of natal homing are unre- 
solved. Our lack of understanding of bluefin tuna's stock structure is of particular concern because spawning stocks, particularly in the west, have declined precipitously over the past few decades (Porch 2005).

Several novel tools are currently being used to quantify the stock structure and extent of mixing between eastern and western Atlantic stocks of bluefin tuna, including electronic tags, genetics, and otolith chemistry (Block et al. 2005, Carlsson et al. 2007, Rooker et al. 2007). Of the 3 , geochemical markers in otoliths (ear stones) have significant potential for quantifying population connectivity because otolith material deposited during the first year of life serves as a natural tag of the individual's place of origin. Otoliths precipitate material (primarily calcium carbonate) as a fish grows and the chemical composition of each newly accreted layer is often associated with physicochemical conditions of the water mass that fish inhabits (Campana 1999, Thresher 1999, Rooker et al. 2001a). As a result, material deposited in the otolith during the first year of life serves as a natural marker of the individual's nursery habitat or place of origin. We have pursued this approach for numerous earth, transition, and heavy metals found in otoliths of Atlantic bluefin tuna and observed differences in juveniles collected from eastern and western nurseries (Secor et al. 2002, Rooker et al. 2003). Still, classification success for several year classes from these studies was moderate (60 to $90 \%$ ) and strong year-to-year variability in chemical signatures occurred, limiting the usefulness of this approach.

Carbon $\left(\delta^{13} \mathrm{C}\right)$ and oxygen $\left(\delta^{18} \mathrm{O}\right)$ stable isotopes in biogenic carbonates represent a class of geochemical markers for which associations with water mass properties are understood (Wilkinson \& Ivany 2002, Grottoli \& Eakin 2007). In otoliths, these isotopes are often related to salinity, temperature, and other physicochemical properties of water (Bastow et al. 2002, Ashford \& Jones 2007), although fractionation due to kinetic and metabolic effects, particularly for $\delta^{13} \mathrm{C}$, also influences isotopic composition (Hoie et al. 2003). Processes affecting seawater $\delta^{18} \mathrm{O}$ and salinity are similar (e.g. evaporation), and otolith $\delta^{18} \mathrm{O}$ varies as a function of salinity and temperature fractionation, with enrichments occurring at higher salinity (i.e. higher evaporation) (Elsdon \& Gillanders 2002, Kerr et al. 2007) and lower temperature (Thorrold et al. 1997, Thebault et al. 2007). Global ocean records indicate that large-scale spatial patterns in surface water $\delta^{18} \mathrm{O}$ exist, with more enriched surface water $\delta^{18} \mathrm{O}$ present in the Mediterranean Sea/eastern Atlantic Ocean region compared to the USA Atlantic Ocean (Schmidt et al. 1999, LeGrande \& Schmidt 2006). Therefore, it appears likely that otolith $\delta^{18} \mathrm{O}$ may serve as a natural marker of nursery origin for bluefin tuna.
Based upon trends in global seawater $\delta^{18} \mathrm{O}$ and a previous pilot study on bluefin tuna (Rooker et al. 2006), we hypothesized that otolith $\delta^{18} \mathrm{O}$ of bluefin tuna from more saline, cooler waters of the eastern Atlantic Ocean and Mediterranean Sea would be enriched relative to individuals from less saline, warmer waters of the western Atlantic Ocean and Gulf of Mexico. To test this assumption, we first characterized the stable isotopic composition in otoliths of yearling bluefin tuna to validate the approach and assess inter-annual variation across 6 year classes (1999 to 2004) from both eastern and western nurseries. Otolith $\delta^{18} \mathrm{O}$ and $\delta^{13} \mathrm{C}$ of yearlings from 6 different year classes were then combined and used as a baseline sample (i.e. reference signatures of 'eastern' and 'western' nurseries) to predict the origin of adolescents from 1 foraging area in the USA Atlantic Ocean and adults from 1 spawning ground (Mediterranean Sea).

\section{MATERIALS AND METHODS}

Yearling bluefin tuna (ca. 1.0 to $1.6 \mathrm{yr}$ old) were collected from several regions in the Mediterranean Sea/eastern Atlantic Ocean and the USA Atlantic Ocean from 1999 to 2004 (Fig. 1, Table 1). Sampling strategies

Table 1. Thunnus thynnus. Collection information for yearlings, adolescents and adults used as baseline sample for mixed-stock analysis. AS: Adriatic Sea; BB: Bay of Biscay/East Atlantic; DE: Delaware; LS: Ligurian Sea; MT: Malta pens; MA: Massachusetts; MD: Maryland; NC: North Carolina; NJ: New Jersey/New York; SP: Spain pens; TS: Tyrrhenian/ Ionian Sea; VA: Virginia

\begin{tabular}{|c|c|c|c|c|}
\hline Year(s) & Region & $\underset{\text { (sample size) }}{\text { Location }} \mathrm{M}$ & $\begin{array}{l}\text { Mean fork length } \\
\text { (cm) (range) }\end{array}$ & $\begin{array}{l}\text { Mean } \\
\text { age }^{\mathrm{a}}\end{array}$ \\
\hline \multicolumn{5}{|l|}{ Yearlings } \\
\hline \multirow[t]{2}{*}{1999} & West & MA (4), NJ (8) & $73(62-83)$ & 1.7 \\
\hline & East & LS (9) & $53(48-55)$ & 1.0 \\
\hline \multirow[t]{2}{*}{2000} & West & NJ (15) & $70(65-74)$ & 1.6 \\
\hline & East & BB (9), LS (30) & $57(49-76)$ & 1.1 \\
\hline \multirow[t]{2}{*}{2001} & West & MA (11) & $60(56-63)$ & 1.2 \\
\hline & East & $\mathrm{BB}(17)$ & $70(68-76)$ & 1.6 \\
\hline \multirow[t]{2}{*}{2002} & West & NJ (10) & $64(62-65)$ & 1.4 \\
\hline & East & AS (20), BB (10) & $65(62-69)$ & 1.4 \\
\hline \multirow[t]{2}{*}{2003} & West & NJ (10) & $65(64-66)$ & 1.4 \\
\hline & East & $\mathrm{BB}(9)$ & $59(56-63)$ & 1.2 \\
\hline \multirow[t]{2}{*}{2004} & West & MA (6), NJ (17) & $63(62-66)$ & 1.3 \\
\hline & East & TS (9) & $68(60-75)$ & 1.5 \\
\hline \multicolumn{5}{|c|}{ Adolescents } \\
\hline $1997-2000$ & West & $\begin{array}{c}\mathrm{DE}(7), \mathrm{MD}(30), \\
\mathrm{NC}(2), \mathrm{NJ}(5), \\
\mathrm{VA}(21)\end{array}$ & $115(97-150)$ & 3.5 \\
\hline $\begin{array}{l}\text { Adults } \\
2003-2006\end{array}$ & East & MT (28), SP (32) & $236(196-285)$ & 12.8 \\
\hline
\end{tabular}



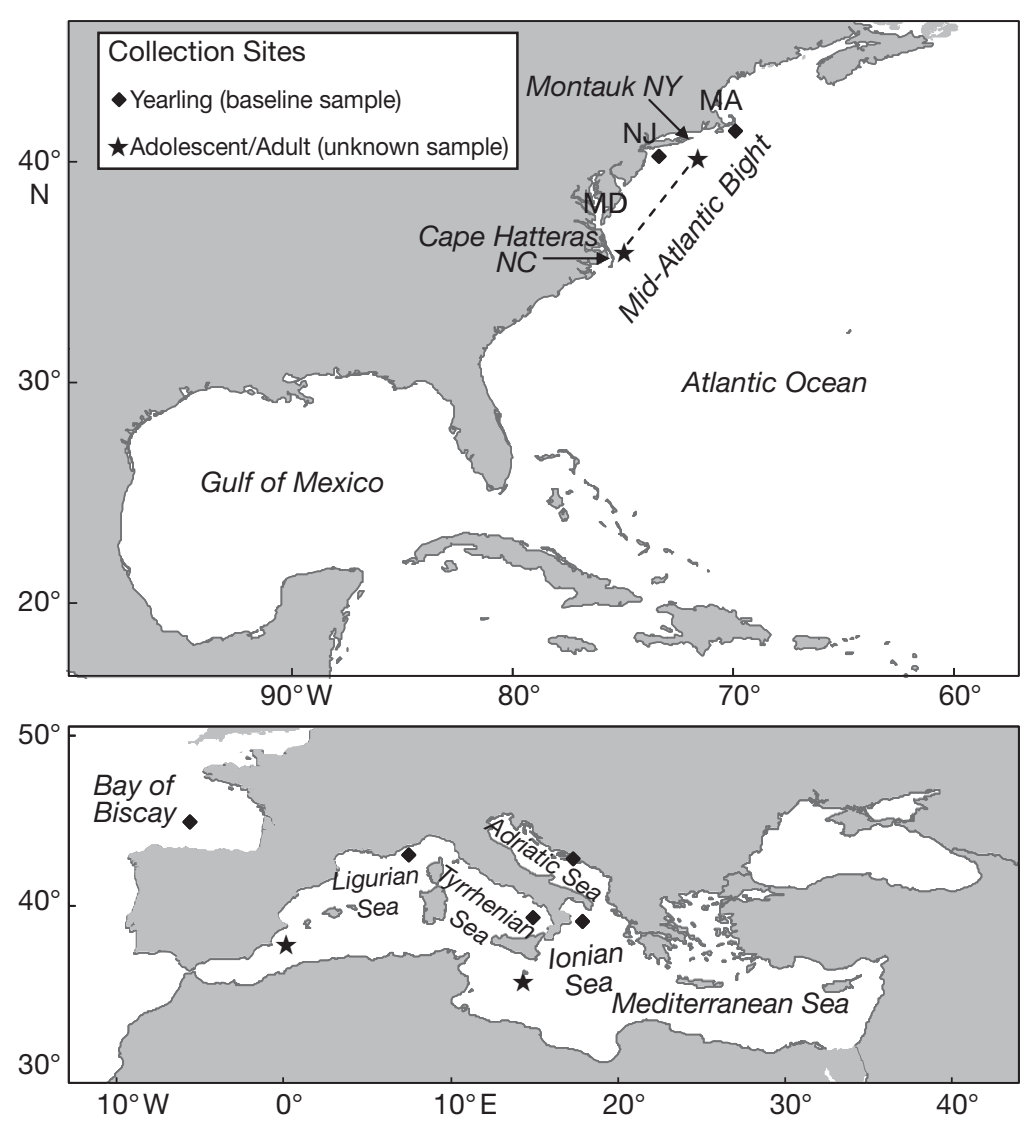

Fig. 1. Thunnus thynnus. Study area with approximate collection sites of yearlings and adolescents/adults shown. Collection sites shown for adults in the Mediterranean Sea represent the location of tuna pens

Bight from Cape Hatteras, North Carolina, to Montauk, New York. A large fraction ( $90 \%)$ of the bluefin tuna used in this study was collected off the coasts of Virginia, Maryland, and Delaware (Table 1). Adult bluefin tuna from the 'spawning ground' were first collected by purse seine vessels in the Mediterranean Sea during summer and then transferred to tuna pen operations. Otolith collections were made when adult bluefin tuna were harvested in the fall from holding pens (ca. 3 to 4 mo after being caught) in Marsaxlokk, Malta (2003) and Murcia, Spain (2004, 2006).

Sagittal otoliths of yearling, adolescent, and adult bluefin tuna were extracted from the cranial cavity and cleaned and rinsed with deionized water $\left(\mathrm{DIH}_{2} \mathrm{O}\right)$ prior to processing on the stable isotope mass spectrometer. Whole otoliths of yearling bluefin were then pulverized (powdered) with an acid-washed mortar and pestle. Sagittal otoliths of adolescent and adult bluefin tuna were embedded in Stuers epoxy resin and sectioned using a low-speed ISOMET saw to obtain $1.5 \mathrm{~mm}$ transverse sections through the core. The thin section was attached to a sample plate and the portion of the otolith cor-

used to procure bluefin tuna varied between regions. In the east, yearlings were either taken by fishermen using hand lines or by commercial long-line fishermen targeting albacore Thunnus alalunga. Two regions of the Mediterranean Sea/eastern Atlantic Ocean were sampled over a 6 yr period (1999 to 2004) — Ligurian Sea to Adriatic Sea: 1999, 2000, 2002, and 2004 (western/central Mediterranean Sea); Bay of Biscay: 2000, 2001, 2002, and 2003 (eastern Atlantic Ocean). In the west, yearling bluefin tuna were collected from the recreational hookand-line fishery in the same general region (New Jersey and Massachusetts).

Large school to medium category ( 20 to $70 \mathrm{~kg}$; ca. 3 to $6 \mathrm{yr}$ old) and giant category (>140 kg; ca. $>10 \mathrm{yr}$ old) bluefin tuna were collected from 1997 to 2000 and from 2003 to 2006, respectively. To simplify, use of the terms 'adolescent' and 'adult' bluefin tuna will refer to individuals of 20 to 70 and $>140 \mathrm{~kg}$, respectively (terminology based on reproductive schedule of western population, Rooker et al. 2007). Adolescent bluefin tuna were collected in the USA Atlantic from 1997 to 2000 by NOAA Fisheries under the Bluefin Year Program (BYP). Collection sites were all within the Mid-Atlantic responding to the yearling period was identified (based on a template derived from sectioned otoliths of yearlings 62 to $64 \mathrm{~cm}$ fork length, ca. $1.2 \mathrm{yr}$ old; Fig. 2). The resulting drill path was then programmed into the New Wave MicroMill System and approximately 25 to 30 passes were made at 40 to $50 \mu \mathrm{m}$ depth per pass to isolate core material from each otolith. Surface profiles were constructed for each otolith to correct for beveling in the section. Cored material was displaced as an intact prism from the section and rinsed with deionized water. Similar to whole otoliths of yearlings, otolith cores from adolescents and adults were pulverized with a mortar and pestle.

Carbon and oxygen stable isotopic ratios of otoliths $\left(\delta^{13} \mathrm{C}\right.$ and $\delta^{18} \mathrm{O}$ represent isotopic ratios of ${ }^{13 / 12} \mathrm{C}$ and ${ }^{18 / 16} \mathrm{O}$ relative to a standard, respectively) were measured on stable isotope mass spectrometers maintained at 3 locations: (1) Isotope Geochemistry Laboratory, Department of Geology, University of Maryland (UM); (2) Stable Isotope Laboratory, University of Houston $(\mathrm{UH})_{i}$ and (3) Environmental Isotope Laboratory, Department of Geosciences, University of Arizona (UA). Stable $\delta^{13} \mathrm{C}$ and $\delta^{18} \mathrm{O}$ isotopes are reported rela- 


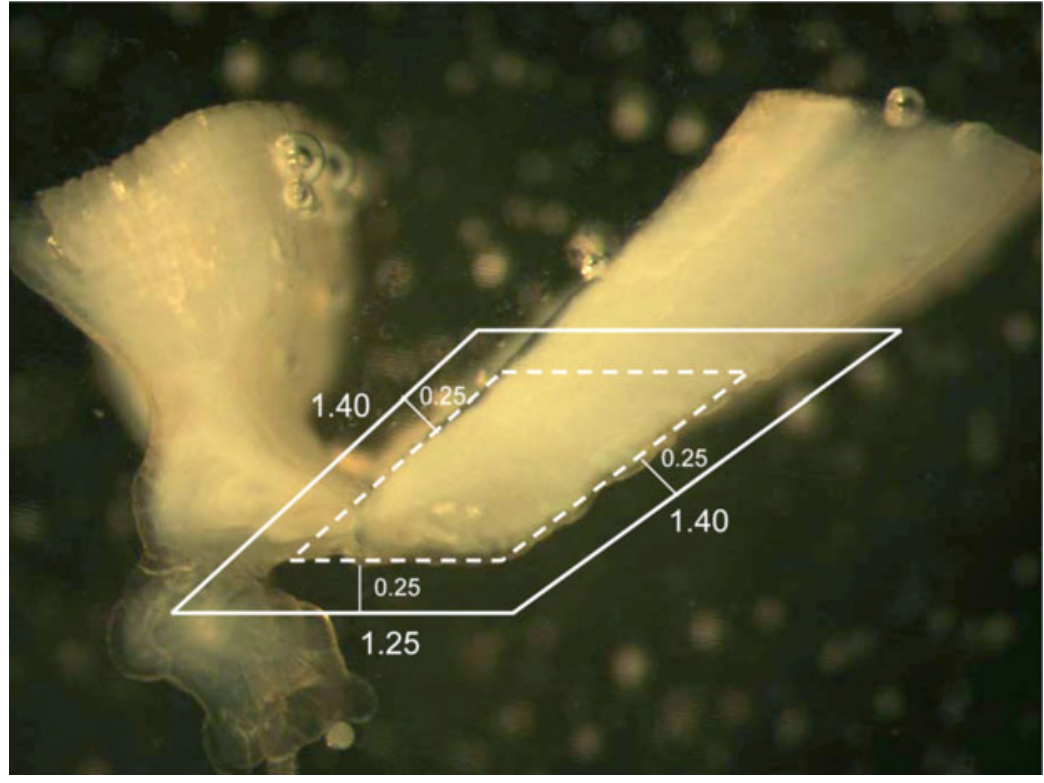

Fig. 2. Thunnus thynnus. Transverse section of sagittal otolith from an adult (age 10) showing the template (lines in $\mathrm{mm}$ ) for milling out the 'yearling' section. The margin of the template was $0.25 \mathrm{~mm}$ outside the otolith to account for the drill bit. Cored material was displaced as an intact prism (denoted with dashed lines)

tive to the Pee Dee Belemnite (PDB) scale after comparison with in-house laboratory standards that were calibrated to PDB. Inter-laboratory comparisons were performed with powder from the same otolith or otolith pairs from the same individuals run at different facilities. Overall, $\delta^{13} \mathrm{C}$ values did not differ significantly (mean difference $=0.03 \%$, paired $t$-test, $p>0.05$ ) among labs and no adjustments were made; however, $\delta^{18} \mathrm{O}$ varied significantly (paired $t$-test, $\mathrm{p}<0.01$ ): (1) $\mathrm{UH}$ versus UM: mean difference $=-0.25 \%$, $\mathrm{n}=14, \mathrm{SD}=$ 0.21 ; (2) UA versus UM: mean difference $=0.26 \%$, $\mathrm{n}=$ $10, \mathrm{SD}=0.24$. Therefore, $\delta^{18} \mathrm{O}$ values were adjusted to account for lab-specific variation. In addition, cored regions of otoliths from adolescent and adult bluefin tuna were used to represent the yearling signature; thus we ran paired comparisons (whole otolith versus sectioned/milled otolith of the same yearling) to determine whether otolith core $\delta^{13} \mathrm{C}$ and $\delta^{18} \mathrm{O}$ matched the whole otolith value. Paired $t$-tests showed no significant difference between cores from transverse sections and whole otoliths in either $\delta^{13} \mathrm{C}$ (mean difference $=$ $0.12 \%, \mathrm{n}=21, \mathrm{p}>0.05$ ) or $\delta^{18} \mathrm{O}$ (mean difference $=$ $0.07 \%$, $\mathrm{n}=21, \mathrm{p}>0.05)$, indicating that our micromilling protocol did not deplete or enrich the core signatures. In fact, mean error between core and whole otolith $\delta^{13} \mathrm{C}$ and $\delta^{18} \mathrm{O}$ was similar to the estimated precision of replicated runs.

ANOVA was used to test for year and region effects on otolith $\delta^{13} \mathrm{C}$ and $\delta^{18} \mathrm{O}$ of yearling bluefin tuna.
Nursery area and year were used as fixed factors in ANOVA models. A multivariate analysis of variance (MANOVA) with region nested within year was also performed, and Pillai trace $(\mathrm{V})$ was chosen as the test statistic as it is the most robust to violations of homogeneity of covariance (Wilkinson et al. 1996). Since the variance-covariance matrix of predictor variables was dissimilar between samples from the east and west, quadratic discriminant function analysis (DFA) was used to classify yearling bluefin tuna from different nurseries and/or year classes. Small differences in otolith weights and fish lengths occurred between sites and among years; however, no effect of size was detected and thus we did not adjust for differences in otolith weight among yearling bluefin tuna.

A maximum likelihood mixed-stock analysis 'HISEA' developed by Millar (1990) was used to predict the nursery origin of adolescent and adult bluefin tuna. The baseline data set comprised otolith $\delta^{13} \mathrm{C}$ and $\delta^{18} \mathrm{O}$ values of yearling bluefin from the eastern and western nurseries, and all regions and year classes within each nursery were pooled to obtain a representative baseline data set. Mixed-stock assessments were conducted on otolith cores (corresponding to the yearling period) of bluefin tuna collected from 2 regions: (1) USA Atlantic Ocean (foraging area); and (2) Mediterranean Sea (spawning area). Direct maximum likelihood estimates (MLE) of mixed-stock proportions and standard deviations were generated in HISEA by bootstrapping with 500 resampled baselines.

\section{RESULTS}

Otolith $\delta^{13} \mathrm{C}$ and $\delta^{18} \mathrm{O}$ was distinct between yearling bluefin tuna from eastern (Mediterranean Sea/eastern Atlantic Ocean) and western (Gulf of Mexico/USA Atlantic Ocean) nurseries when all year classes were pooled (MANOVA, p < 0.01). ANOVA with both year and region as fixed factors indicated that otolith $\delta^{18} \mathrm{O}$ was significant for both factors $(\mathrm{p}<0.01)$. Eastern samples were enriched in $\delta^{18} \mathrm{O}$ relative to their western counterparts by approximately $0.77 \%$ (Fig. 3): eastern nursery (mean $\delta^{18} \mathrm{O}=-0.89 \pm 0.23, \mathrm{n}=113$ ), western nursery (mean $\delta^{18} \mathrm{O}=-1.66 \pm 0.37, \mathrm{n}=81$ ). A significant interaction term was detected for otolith $\delta^{18} \mathrm{O}$, indicating that the regional differences were not consistent across 

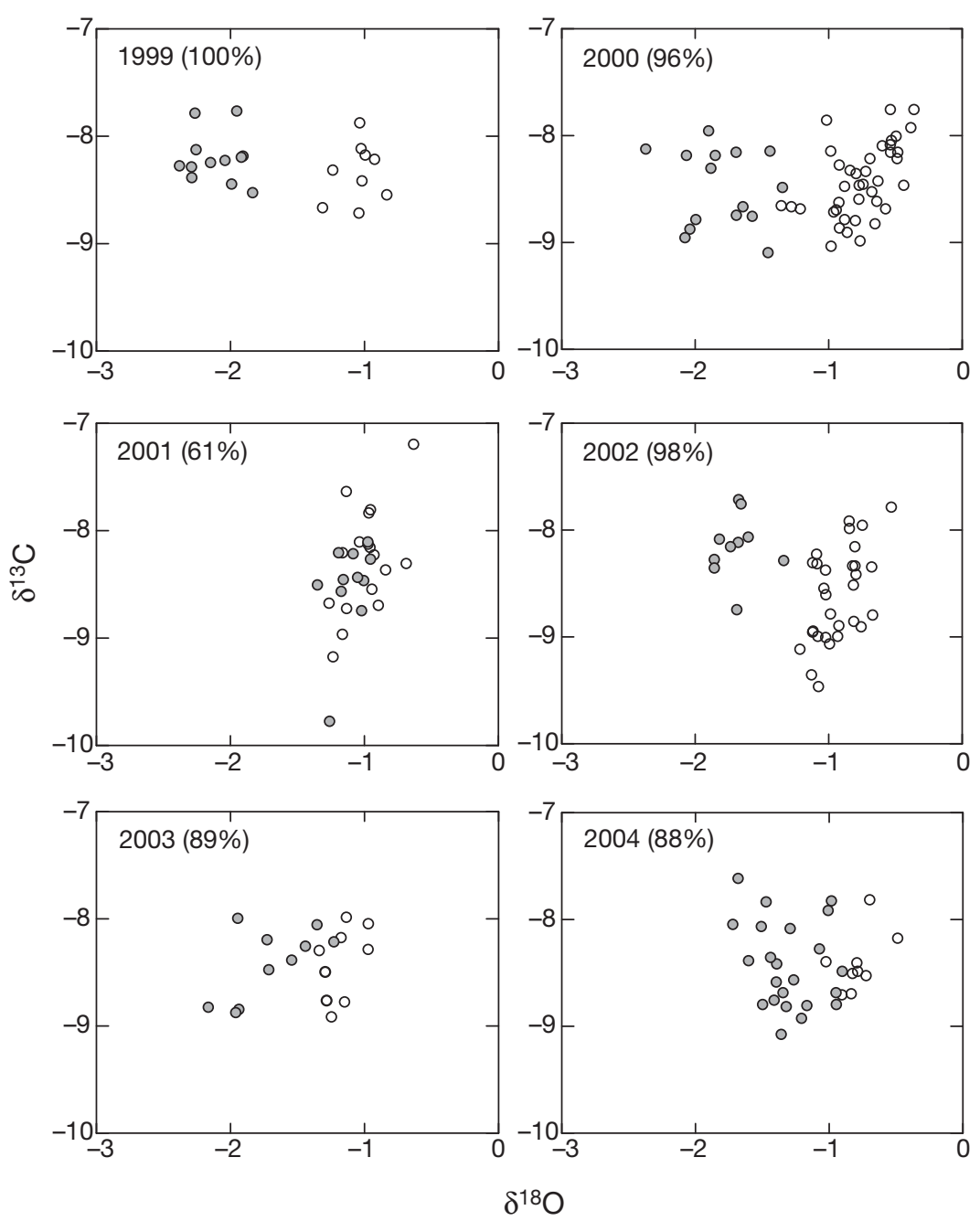

Fig. 3. Thunnus thynnus. Otolith $\delta^{13} \mathrm{C}$ and $\delta^{18} \mathrm{O}$ for 6 year classes (1999 to 2004) of yearlings collected in the eastern Atlantic Ocean/Mediterranean Sea (0) and USA Atlantic Ocean (०). Cross-validated classification success (based on discriminant function analysis) for individual cohorts is shown in parentheses for each year class

years. In contrast, no significant differences (ANOVA, $p$ $>0.05$ ) in otolith $\delta^{13} \mathrm{C}$ were observed by year or region for yearling bluefin tuna. The mean difference in otolith $\delta^{13} \mathrm{C}$ of yearling bluefin tuna collected from the Mediterranean Sea/eastern Atlantic Ocean (mean $\delta^{13} \mathrm{C}=-8.46 \pm$ 0.42 ) and USA Atlantic Ocean (mean $\delta^{13} \mathrm{C}=-8.37 \pm 0.36$ ) was only $0.09 \%$.

Inter-annual variability in otolith $\delta^{18} \mathrm{O}$ of bluefin tuna was evident within both the eastern and western samples. Still, cross-validated classification success from DFA was relatively high $(87 \%)$ when all 6 year classes were pooled. Classification success by region with all 6 year classes pooled was 92 and $79 \%$ for eastern and western yearlings, respectively. Classification success for DFA models based entirely on $\delta^{18} \mathrm{O}$ or $\delta^{13} \mathrm{C}$ was 86 and $52 \%$, respectively. Since expected classification is $50 \%$ based on random assignment, the discriminatory power of $\delta^{13} \mathrm{C}$ was insignificant. The yearling signature of eastern bluefin tuna was very distinct, even though the baseline data set was comprised of individuals from the eastern Atlantic Ocean and 5 areas of the western and central Mediterranean Sea. Cross-validated classification success from DFA for individual cohorts was greater than $88 \%$ in 5 of the 6 year classes examined: $1999,100 \%(\mathrm{n}=21) ; 2000,96 \%$ $(\mathrm{n}=54) ; 2001,61 \%(\mathrm{n}=28) ; 2002,98 \%$ $(\mathrm{n}=40) ; 2003,89 \%(\mathrm{n}=10) ; 2004,88 \%$ ( $\mathrm{n}=32$ ).

Otolith core $\delta^{13} \mathrm{C}$ and $\delta^{18} \mathrm{O}$ of adolescent bluefin tuna $(\mathrm{n}=65)$ collected in the USA Atlantic Ocean were compared to reference samples to determine nursery origin. Observed otolith core $\delta^{18} \mathrm{O}$ of adolescents ranged from -0.8 to -1.9 ; $\delta^{13} \mathrm{C}$ values ranged from -7.0 to -10.2 (Fig. 4). Direct maximum likelihood estimates indicated that the stock was mixed, with $61 \%$ of the adolescent bluefin tuna originating from the eastern nursery. The remaining adolescents $(39 \%)$ in this region were classified as western Atlantic stock, indicating that individuals on this western foraging area were comprised mainly of eastern recruits from the Mediterranean Sea. $\mathrm{SD}$ around estimated proportions was $9 \%$; therefore there was a $68 \%$ probability that the eastern Atlantic contribution to the adolescent population sampled from the west was between 52 and $70 \%$.

Otolith core $\delta^{13} \mathrm{C}$ and $\delta^{18} \mathrm{O}$ of adult bluefin tuna ( $\mathrm{n}=$ 60) collected from the Mediterranean Sea were compared to reference samples to assess the degree of natal homing. Otolith core $\delta^{18} \mathrm{O}$ values ranged from -1.2 to -2.3 , with the majority of cores being enriched with $\delta^{18} \mathrm{O}$, indicative of eastern origin; otolith core $\delta^{13} \mathrm{C}$ composition ranged from -7.0 to -9.3 (Fig. 5). Mixed-stock analysis indicated that natal homing was well developed, with $94 \%$ of the bluefin tuna in our sample being classified as Mediterranean fish. SD around the estimated proportions was $4 \%$, indicating a $68 \%$ probability that 90 to $98 \%$ of the bluefin tuna collected from spawning grounds in the Mediterranean Sea were produced from nurseries in this region. 

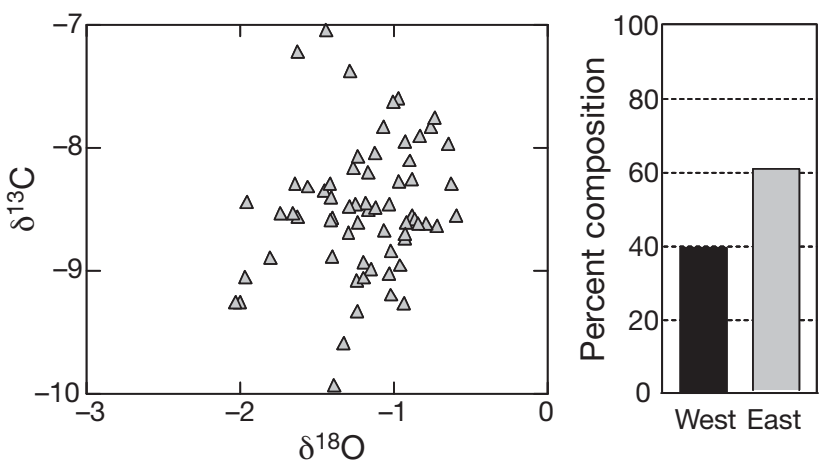

Fig. 4. Thunnus thynnus. Otolith core $\delta^{13} \mathrm{C}$ and $\delta^{18} \mathrm{O}$ of adolescents (30 to $140 \mathrm{~kg}$ ) collected in the USA Atlantic Ocean from 1997 to 2000. Percent composition estimates derived from mixed-stock analysis (right) indicate the nursery origin (eastern versus western nursery) of adolescents. Yearling signatures from 1999 to 2004 were used as baseline data (i.e. fish of known origin) to estimate nursery origin
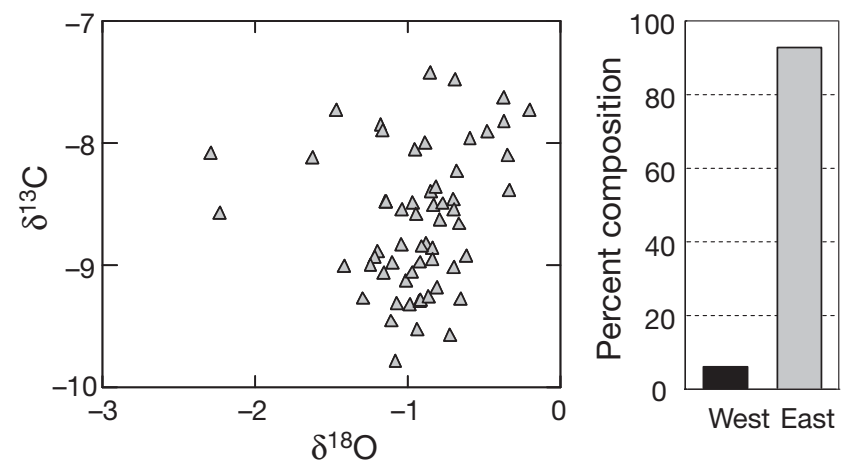

Fig. 5. Thunnus thynnus. Otolith core $\delta^{13} \mathrm{C}$ and $\delta^{18} \mathrm{O}$ of adults $(>140 \mathrm{~kg}$ ) collected from the Mediterranean Sea 'spawning ground' in 2003, 2004, and 2006. Percent composition estimates derived from mixed-stock analysis (right) indicate the nursery origin (eastern versus western nursery) of adults from the Mediterranean 'spawning' ground. Yearling signatures from 1999 to 2004 were used as baseline data (i.e. fish of known origin) to estimate nursery origin

\section{DISCUSSION}

Several studies have demonstrated that otolith $\delta^{13} \mathrm{C}$ and $\delta^{18} \mathrm{O}$ serve as useful markers of natal source or environmental history for fishes, particularly in estuarine and coastal environments (Thorrold et al. 2001, Dorval et al. 2007, Kerr et al. 2007). Applications of stable isotopes as natural markers in oceanic or pelagic ecosystems are far less common (Dufour et al. 1998), despite the fact that large-scale differences in seawater $\delta^{13} \mathrm{C}$ and $\delta^{18} \mathrm{O}$ exist (Rau et al. 1989, Quay et al. 1992, Goericke \& Fry 1994, Schmidt et al. 1999). Our data showed that otolith $\delta^{18} \mathrm{O}$ is valuable for distin- guishing bluefin tuna from the eastern and western nurseries, while otolith $\delta^{13} \mathrm{C}$ was similar between nurseries. Otolith $\delta^{18} \mathrm{O}$ of bluefin tuna from the cooler and more saline waters in the Mediterranean Sea/ eastern Atlantic Ocean was significantly enriched $\left(\delta^{18} \mathrm{O}\right.$ higher by $0.8 \%$ ) relative to individuals from the USA Atlantic Ocean. Observed spatial variation in $\delta^{18} \mathrm{O}$ between nurseries was consistent with global patterns in the oxygen isotopic ratio of seawater (LeGrande \& Schmidt 2006), suggesting that otolith $\delta^{18} \mathrm{O}$ is closely tied to seawater $\delta^{18} \mathrm{O}$ for bluefin tuna and likely independent of kinetic and metabolic effects (Hoie et al. 2003).

Otolith $\delta^{18} \mathrm{O}$ of bluefin tuna within the eastern nursery was similar across years even though samples were drawn from different regions. Thus, otolith $\delta^{18} \mathrm{O}$ and the factors known to affect seawater $\delta^{18} \mathrm{O}$ (e.g. rainfall, surface air temperature, and evaporation and/or water vapor isotopic composition) were relatively stable in the Mediterranean Sea/eastern Atlantic Ocean at these large spatial scales during the period of this investigation. Still, otolith $\delta^{18} \mathrm{O}$ of bluefin tuna from the western nursery were quite variable, even though yearling samples were collected from a restricted area of the USA Atlantic Ocean, ranging from New Hampshire to Massachusetts. While inter-annual variability in seawater $\delta^{18} \mathrm{O}$ is common in marginal seas and may reflect natural fluctuations in physicochemical conditions of the seawater (Grottoli \& Eakin 2007), it is also possible that differences in retention times of juveniles in the Gulf of Mexico may be responsible for observed patterns because seawater $\delta^{18} \mathrm{O}$ between spawning and collection sites was dissimilar (LeGrande \& Schmidt 2006). The latitudinal gradient (north-south component) in water masses and/or seawater $\delta^{18} \mathrm{O}$ experienced by western bluefin tuna was not present in eastern sample areas and this may have contributed to higher cohort-specific variability in otolith $\delta^{18} \mathrm{O}$ of western yearlings.

One year class, the 2001 western Atlantic cohort, was enriched relative to other year classes in the western baseline sample. In fact, this cohort was indistinguishable from the eastern baseline sample. Physicochemical conditions experienced by the 2001 year class in the west were similar to other years in our baseline (Boyer et al. 2006), and observed differences in otolith $\delta^{18} \mathrm{O}$ were unlikely linked to shifts in temperature or salinity in the Gulf of Mexico or western Atlantic Ocean. We speculate that similarities in otolith $\delta^{18} \mathrm{O}$ of eastern and western bluefin tuna in 2001 may indicate that some individuals collected from the USA Atlantic Ocean in 2001, and possibly certain individuals from other years, originated in the Mediterranean Sea. Trans-oceanic migratory behavior is common for Pacific bluefin tuna Thunnus orientalis, which often 
move from the western Pacific Ocean to areas off the coast of the USA and Mexico during the juvenile period (age 0 and age 1) (Bayliff et al. 1991, Bayliff 1994). Similarly, east to west movement of juvenile bluefin tuna (age 1 to age 2) tagged in the Cantabrian Sea has been documented (Cort \& de la Serna 1994, Cort \& Liorzou 1995, Rodríguez-Marín et al. 2005). It is possible that yearlings in our 2001 sample represented a group of Mediterranean-origin juveniles that had crossed the Atlantic Ocean; this would explain their enriched otolith $\delta^{18} \mathrm{O}$. To evaluate the impact of this group, we omitted the 2001 samples collected in the USA Atlantic Ocean from the 1999 to 2004 baseline data to obtain MLE of mixed-stock proportions. Even though overall classification success from DFA increased to $91 \%$, estimates of percent origin were similar to models run with the complete baseline data. Eastern contribution of adolescents increased by $6 \%$; however, no change occurred in mixed stock proportions of adults in the Mediterranean Sea.

Evidence of trans-Atlantic movement was demonstrated here for adolescent bluefin tuna, with the majority of individuals present in the USA Atlantic Ocean derived from the Mediterranean Sea ( 60\%). Our results indicate that east to west movement was significant and that intermingling of populations occurred in the USA Atlantic Ocean. Observed estimates of trans-Atlantic movement based on otolith $\delta^{18} \mathrm{O}$ are markedly higher than predicted from conventional tagging data (Magnuson et al. 1994, Fromentin, 2001). Because time at liberty is often less than $1 \mathrm{yr}$ with conventional tags and recaptures are fisherydependent with questionable reporting rates outside the host country, the value of conventional tag data for documenting trans-Atlantic movement has been questioned (Rooker et al. 2007). In contrast, recent findings from archival tagging research on bluefin tuna showed that eastern and western bluefin tuna populations intermingle in the North American shelf and slope waters of the USA Atlantic Ocean (Block et al. 2005), supporting our otolith $\delta^{18} \mathrm{O}$-based predictions. Lightbased geo-location estimates obtained from archival tags indicated that a significant fraction of the bluefin tuna on foraging grounds off the USA's Atlantic coast was composed of bluefin tuna classified as 'eastern' spawners. Based on both otolith $\delta^{18} \mathrm{O}$ and archival tag data, it appears that stock mixing of adolescent bluefin tuna is significant in USA waters and that the fishery in this region may depend heavily on recruits from the eastern population.

Although adolescent bluefin tuna from the eastern population appear to actively mix on foraging grounds west of the $45^{\circ} \mathrm{W}$ management boundary, otolith $\delta^{18} \mathrm{O}$-based estimates of origin showed that natal homing back to the Mediterranean Sea was well devel- oped. More than $90 \%$ of the adult bluefin tuna collected from the Mediterranean Sea matched the baseline signature of the eastern nursery, indicating that adolescents eventually return to their natal site. Support for spawning-site fidelity of bluefin tuna has been recently documented through the use of archival tags with 3 to 4 yr deployment records, with several individuals returning to the Mediterranean spawning ground in consecutive years (Block et al. 2005, Rooker et al. 2007). Natal homing to the Gulf of Mexico has also been assumed for bluefin tuna, based on archival tags, but data supporting this premise are limited (Block et al. 2005). Further investigations using stable isotopic signatures are needed to fully evaluate natal homing for the Gulf of Mexico population.

Inter-annual variability in the chemical composition of otoliths is well documented (e.g. Rooker et al. 2001b, Gillanders 2002, Dorval et al. 2007) and temporal variability in otolith chemistry often necessitates the matching of sub-adults or adults to juveniles from specific year classes (Gillanders 2005). We believe the temporal stability of the primary marker, $\delta^{18} \mathrm{O}$, justified the pooling of year classes for establishing a baseline and minimized the need for age-class matching. Although local climactic conditions (evaporation versus precipitation) have been shown to affect seawater $\delta^{18} \mathrm{O}$ within the Mediterranean Sea (Pierre 1999), variability between eastern and western Atlantic nurseries was greater than inter-annual variability within each nursery, suggesting that these natural markers were relatively stable over the period investigated. Conversely, inter-annual and inter-decadal variation in $\delta^{13} \mathrm{C}$ has been documented, with $\delta^{13} \mathrm{C}$ becoming more depleted in the atmosphere and oceans due to the release of $\mathrm{CO}_{2}$ depleted in the heavier $\delta^{13} \mathrm{C}$ isotope (Keeling 1979, Quay et al. 1992, Verburg 2007). The effect of $\delta^{13} \mathrm{C}$ depletion in the oceans over time (i.e. decades) may be problematic when comparing current samples (i.e. 1999 to 2004 yearling data) to those from bluefin tuna hatched decades before the baseline period. Otolith $\delta^{13} \mathrm{C}$ did not differ between regions in our baseline data; thus the impact of this effect on our predictions of nursery origin was insignificant. Still, caution must be exercised when linking baseline data and unknown samples from different time periods, and the addition of new years to the baseline data setalong with the development of an otolith core $\delta^{13} \mathrm{C}$ relationship with birth date-will improve future assessments using this approach.

Findings from this investigation indicate that otolith $\delta^{18} \mathrm{O}$ serves as a reliable marker of nursery origin for bluefin tuna. Moreover, our application of the approach resulted in 2 significant findings: (1) trans-Atlantic movement of adolescents from east to west occurs, indicating that USA fisheries currently depend upon mi- 
grants of Mediterranean origin; and (2) natal homing of bluefin tuna to the Mediterranean Sea is well developed. Both observations improve our present understanding of bluefin tuna stock structure, which is critical for proper management of international bluefin tuna fisheries (Fromentin \& Powers 2005).

Acknowledgements. We thank E. Rodriguez-Marin, L. Orsi Relini, M. Deflorio, N. Santamaria, G. Palandri, G. Skomal, M. Relini, S. McGuire, R. Wingate, and J. Graves for assisting with collections of yearling bluefin tuna. A special thanks to $\mathrm{S}$. Turner and R. Schloesser for their contributions to this project. In addition, we are grateful for the access to tuna pens provided by T.F.M Tuna Farms of the Mediterraneo S.L. (Spain), Tuna Graso, S.A. (Spain) and Fish and Fish Ltd. (Malta). This work was supported by grants from NOAA Fisheries and the Large Pelagic Research Center, University of New Hampshire.

\section{LITERATURE CITED}

Ashford J, Jones C (2007) Oxygen and carbon stable isotopes in otoliths record spatial isolation of Patagonian toothfish (Dissostichus eleginoides). Geochim Cosmochim Acta 71: 87-94

Bastow TP, Jackson G, Edmonds JS (2002) Elevated salinity and isotopic composition of fish otolith carbonate: stock delineation of pink snapper, Pagrus auratus, in Shark Bay, Western Australia. Mar Biol 141:801-806

Bayliff WH (1994) A review of the biology and fisheries for northern bluefin tuna, Thunnus thynnus, in the Pacific Ocean. FAO Fish Tech Pap 336:244-295

Bayliff WH, Ishizuka Y, Deriso RB (1991) Growth, movement, and attrition of northern bluefin tuna (Thunnus thynnus) in the Pacific Ocean as determined by tagging. Bull Int Am Tropic Tuna Comm 20:1-94

Block BA, Dewar H, Blackwell SB, Williams TD and others (2001) Migratory movements, depth preferences, and thermal biology of Atlantic bluefin tuna. Science 293: 1310-1314

Block BA, Teo SLH, Walli A, Boustany A and others (2005) Electronic tagging and population structure of Atlantic bluefin tuna. Nature 434:1121-1127

Boyer TP, Antonov JI, Garcia HE, Johnson DR and others (2006) World Ocean Database. In: Levitus S (ed) NOAA Atlas NESDIS 60. US Government Printing Office, Washington, DC

Campana SE (1999) Chemistry and composition of fish otoliths: pathways, mechanisms and applications. Mar Ecol Prog Ser 188:263-297

Carlsson J, McDowell JR, Carlsson L, Graves JE (2007) Genetic identity of YOY bluefin tuna from the Eastern and Western Atlantic spawning areas. Heredity 98:23-25

Cort JL (1991) Age and growth of bluefin tuna (Thunnus thynnus L.) of the Northwest Atlantic. Intl Comm Conserv Atlantic Tuna Col Vol Sci Pap 35:213-230

Cort JL, de la Serna JM (1994) Revision de los datos de marcado/recaptura de atún rojo (Thunnus thynnus) en el Atlántico oriental y Mediterráneo. Intl Comm Conserv Atlantic Tuna Col Vol Sci Pap 42:255-259

Cort JL, Liorzou B (1995) Revision del marcado/recaptura de atun rojo (Thunnus thynnus) en el Atlántico Este y Mediterráneo. Intl Comm Conserv Atlantic Tuna Col Vol Sci Pap 44:293-304
Dorval E, Jones CM, Hannigan R, van Montfrans J (2007) Relating otolith chemistry to surface water chemistry in a coastal plain estuary. Can J Fish Aquat Sci 64:411-424

Dufour V, Pierre C, Rancher J (1998) Stable isotopes in fish otoliths discriminate between lagoonal and oceanic residents of Taiaro Atoll (Tuamotu Archipelago, French Polynesia). Coral Reefs 17:23-28

Elsdon TS, Gillanders BM (2002) Interactive effects of temperature and salinity on otolith chemistry: challenges for determining environmental histories of fish. Can J Fish Aquat Sci 59:1796-1808

Fromentin JM (2001) Descriptive analysis of the ICCAT bluefin tuna tagging database. Intl Comm Conserv Atlantic Tuna Col Vol Sci Pap 54:353-362

Fromentin JM, Powers JE (2005) Atlantic bluefin tuna: population dynamics, ecology, fisheries, and management. Fish Fish 6:281-306

> Ghosh P, Elier J, Campana SE, Feeney RF (2007) Calibration of the carbonate 'clumped isotope' paleothermometer for otoliths. Geochim Cosmochim Acta 71(11): $2736-2744$

> Gillanders BM (2002) Temporal and spatial variability in elemental composition of otoliths: implications for determining stock identity and connectivity of populations. Can J Fish Aquat Sci 59:669-679

Gillanders BM (2005) Using elemental chemistry of fish otoliths to determine connectivity between estuarine and coastal habitats. Estuar Coast Shelf Sci 64:47-57

Goericke R, Fry B (1994) Variations of marine plankton $\delta^{13} \mathrm{C}$ with latitude, temperature, and dissolved $\mathrm{CO}_{2}$ in the world ocean. Global Biogeochem Cycles 8:85-90

$>$ Grottoli A, Eakin CM (2007) A review of modern coral $\delta^{18} \mathrm{O}$ and $\delta^{14} \mathrm{C}$ proxy records. Earth Sci Rev 81:67-91

Hoie H, Folkvord A, Otterlei E (2003) Effect of somatic and otolith growth on stable isotopic composition of early juvenile cod (Gadus morhua L) otoliths. J Exp Mar Biol Ecol 289:41-58

Keeling CD (1979) Recent trends in the ${ }^{13} \mathrm{C} /{ }^{12} \mathrm{C}$ ratio of atmospheric carbon dioxide. Nature 277:121-123

Kerr LA, Secor DH, Kraus RT (2007) Stable isotope $\left(\delta^{13} \mathrm{C}\right.$ and $\delta^{18} \mathrm{O}$ ) and $\mathrm{Sr} / \mathrm{Ca}$ composition of otoliths as proxies for environmental salinity experienced by an estuarine fish. Mar Ecol Prog Ser 349:245-253

LeGrande AN, Schmidt GA (2006) Global gridded data set of the oxygen isotopic composition in seawater. Geophys Res Lett 33:L12604

Lutcavage ME, Brill RW, Skomal GB, Chase BC, Howey PW (1999) Results of pop-up satellite tagging of spawning size class fish in the Gulf of Maine: Do North Atlantic bluefin tuna spawn in the mid-Atlantic? Can J Fish Aquat Sci 56:173-177

Magnuson JJ, Block BA, Deriso RB, Gold JR and others (1994) An assessment of Atlantic bluefin tuna. National Academy Press, Washington, DC

> Millar RB (1990) Comparison of methods for estimating mixed stock fishery composition. Can J Fish Aquat Sci 47: 2235-2241

Pierre C (1999) The oxygen and carbon isotope distribution in the Mediterranean water masses. Mar Geol 153:41-55

Porch CE (2005) The sustainability of western Atlantic bluefin tuna: a warm-blooded fish in a hot-blooded fishery. Bull Mar Sci 76:363-384

> Quay PD, Tilbrook B, Wong CS (1992) Oceanic uptake of fossil fuel $\mathrm{CO}_{2}$ : carbon-13 evidence. Science 256:74-79

Rau GH, Takahashi T, Des Marais DJ (1989) Latitudinal variations in plankton $\delta^{13} \mathrm{C}$ : implications for $\mathrm{CO}_{2}$ and productivity in past oceans. Nature 341:516-518 
Rodríguez-Marín E, Rodríguez-Cabello C, De la Serna JM, Cort JL and others (2005) A review of bluefin tuna juveniles tagging information and mortality estimation in waters around the Iberian Peninsula. Intl Comm Conserv Atlantic Tuna Col Vol Sci Pap 58:1388-1402

Rooker JR, Zdanowicz VS, Secor DH (2001a) Chemistry of tuna otoliths: assessment of base composition and postmortem handling effects. Mar Biol 139:35-43

Rooker JR, Secor DH, Zdanowicz VS, Itoh T (2001b) Discrimination of northern bluefin tuna from nursery areas in the Pacific Ocean using otolith chemistry. Mar Ecol Prog Ser 218:275-282

Rooker JR, Secor DH, Zdanowicz VS, De Metrio G, Relini LO (2003) Identification of northern bluefin tuna stocks from putative nurseries in the Mediterranean Sea and western Atlantic Ocean using otolith chemistry. Fish Oceanogr 12:75-84

Rooker JR, Secor DH, De Metrio G, Rodriguez-Marin E (2006) Evaluation of population structure and mixing rates of Atlantic bluefin tuna from chemical signatures in otoliths. Intl Comm Conserv Atlantic Tuna Col Vol Sci Pap 59: 813-818

Rooker JR, Alvarado Bremer JR, Block BA, Dewar H and others (2007) Life history and stock structure of Atlantic bluefin tuna (Thunnus thyunnus). Rev Fish Sci 15:265-310

Schmidt GA, Biggs GR, Rohling EJ (1999) Global Seawater Oxygen-18 database. NASA Goddard Institute for Space Studies, New York. Available at: http://data.giss.nasa. gov/o18data/

Secor DH, Campana SE, Zdanowicz VS, Lam JWH, McLaren JW, Rooker JR (2002) Inter-laboratory comparison of

Editorial responsibility: Hans Heinrich Janssen, Oldendorf/Luhe, Germany
Atlantic and Mediterranean bluefin tuna otolith microconstituents. ICES J Mar Sci 59:1294-1304

Thebault J, Chauvaud L, Clavier J, Guarini J and others (2007) Reconstruction of seasonal temperature variability in the tropical Pacific Ocean from the shell of a scallop, Comptopallium radula. Geochim Cosmochim Acta 71: 918-928

Thorrold SR, Campana SE, Jones CM, Swart PK (1997) Factors determining $\delta^{13} \mathrm{C}$ and $\delta^{18} \mathrm{O}$ fractionation in aragonitic otoliths of marine fish. Geochim Cosmochim Acta 61: 2909-2919

Thorrold SR, Latkoczy C, Swart PK (2001) Natal homing in a marine fish metapopulation. Science 291:297-299

Thresher RE (1999) Elemental composition of otoliths as a stock delineator in fishes. Fish Res 43:165-204

Turner SC, Restrepo VR (1994) A review of the growth rate of west Atlantic bluefin tuna, Thunnus thynnus, estimated from marked and recaptured fish. Intl Comm Conserv Atlantic Tuna Col Vol Sci Pap 42:170-172

> Verburg P (2007) The need to correct for the Suess effect in the application of $\delta^{13} \mathrm{C}$ in sediment of autotrophic Lake Tanganyika, as a productivity proxy in the Anthropocene. J Paleolimnol 37:591-602

Wilkinson BH, Ivany LC (2002) Paleoclimatic inference from stable isotope profiles of accretionary biogenic hardparts; a quantitative approach to the evaluation of incomplete data. Palaeogeogr Palaeoclimatol Palaeoecol 185:95-114

Wilkinson L, Blank G, Gruber C (1996) Desktop data analysis with SYSTAT. Prentice Hall, Upper Saddle River, NJ

Submitted: February 27, 2008; Accepted: June 10, 2008 Proofs received from author(s): September 10, 2008 